\section{(6) OPEN ACCESS}

\begin{abstract}
- Additional material is published online only. To view please visit the journal online (http://dx.doi.org/10.1136/ archdischild-2015-308283).

${ }^{1}$ Paediatric Infectious Disease Unit, Hôpital Universitaire des Enfants Reine Fabiola (HUDERF), Université Libre de Bruxelles, Brussels, Belgium ${ }^{2}$ Unit of Epidemiology and Infectious Diseases, Scientific Institute of Public Health (SIPH), Brussels, Belgium
\end{abstract}

\section{Correspondence to}

Professor Philippe Lepage, Paediatric Infectious Disease Unit, Hôpital Universitaire des Enfants Reine Fabiola, JJ Crocq avenue, 15 Brussels 1020, Belgium; philippe.lepage@huderf.be

Received 20 January 2015 Accepted 26 May 2015 Published Online First 30 June 2015

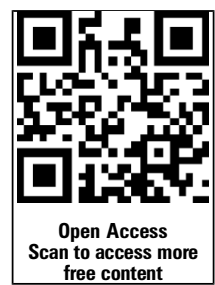

\section{SLinked}

- http://dx.doi.org/10.1136/ archdischild-2015-308730

\section{CrossMark}

\section{To cite: Blumental $S$,}

Sabbe M, Lepage $\mathrm{P}$, et al.

Arch Dis Child

2016;101:16-22.

\title{
Varicella paediatric hospitalisations in Belgium: a 1-year national survey
}

\author{
Sophie Blumental, ${ }^{1}$ Martine Sabbe, ${ }^{2}$ Philippe Lepage, ${ }^{1}$ the Belgian Group for Varicella
}

\begin{abstract}
Background Varicella universal vaccination (UV) has been implemented in many countries for several years. Nevertheless, varicella UV remains debated in Europe and few data are available on the real burden of infection. We assessed the burden of varicella in Belgium through analysis of hospitalised cases during a 1-year period. Methods Data on children admitted to hospital with varicella were collected through a national network from November 2011 to October 2012. Inclusion criteria were either acute varicella or related complications up to 3 weeks after the rash.
\end{abstract}

Results Participation of 101 hospitals was obtained, covering $97.7 \%$ of the total paediatric beds in Belgium. 552 children were included with a median age of 2.1 years. Incidence of paediatric varicella hospitalisations reached $29.5 / 10^{5}$ person-years, with the highest impact among those $0-4$ years old (global incidence and odds of hospitalisation: $79 / 10^{5}$ person-years and $1.6 / 100$ varicella cases, respectively). Only $14 \%$ (79/552) of the cohort had an underlying chronic condition. 65\% (357/ 552) of children had $\geq 1$ complication justifying their admission, $49 \%$ were bacterial superinfections and $10 \%$ neurological disorders. Only a quarter of children (141/ 552) received acyclovir. Incidence of complicated hospitalised cases was $19 / 10^{5}$ person-years. Paediatric intensive care unit admission and surgery were required in $4 \%$ and $3 \%$ of hospitalised cases, respectively. Mortality among Belgian paediatric population was $0.5 / 10^{6}$ and fatality ratio $0.2 \%$ among our cohort.

Conclusions Varicella demonstrated a substantial burden of disease in Belgian children, especially among the youngest. Our thorough nationwide study, run in a country without varicella UV, offers data to support varicella UV in Belgium.

\section{INTRODUCTION}

Varicella (chickenpox), caused by the varicella-zoster virus (VZV), usually presents as a vesicular eruption associated with general symptoms like fever and malaise. Endemic worldwide, this infection is selflimiting in the vast majority of infected individuals. $^{1}{ }^{2}$ However, some complications are commonly described, mainly skin or disseminated bacterial superinfections, central nervous system disturbances, pneumonia and haematological disorders. ${ }^{1}{ }^{2}$ Although these complications are more frequent and severe in high-risk subgroups (adults and adolescents, pregnant women, immunocompromised patients), they can also affect otherwise healthy children and subsequently increase the burden of the disease, in addition to its high societal and economic impact.

\section{What is already known on this topic?}

- Varicella is usually a self-limiting disease but complications are commonly described. Universal vaccination (UV) against varicella has shown good results in some countries but is not largely implemented in Europe.

- Reliable data on the incidence and clinical epidemiology of varicella among hospitalised children are lacking in many countries, notably Belgium.

\section{What does this study add?}

- This study shows a high burden of varicella disease among otherwise healthy Belgian children, as reflected by a significant incidence of paediatric varicella hospitalisation and substantial rates of complications.

- The highest impact was observed among the 0-4 years old children.

- Our thorough nationwide study provides recent data to support UV against varicella in Belgium.

Safe and effective live-attenuated vaccines against varicella were developed in the 1970 s. $^{3}$ Consequently, varicella universal vaccination (UV) has been implemented for $>10$ years in many countries such as the USA, Canada, Australia and Germany, showing conclusive efficacy results. ${ }^{4-9}$ According to recent American and European studies, UV actually resulted in a decrease of at least $88 \%$ in varicella incidence, mortality, complicated cases and hospitalisations. ${ }^{4-11}$ Even though a slight shift of incidence peak was noticed towards older children, the vaccination's impact was demonstrated to be significant among all age groups. ${ }^{6}{ }^{10-12}$ Based on long-term epidemiological surveillance, a global consensus was achieved to recommend a 2-dose schedule, in order to avoid breakthrough outbreaks and improve vaccine effectiveness and herd protection. ${ }^{13}$

Nevertheless, most European countries remain hesitant to implement varicella UV (only implemented in 5 out of 28 European Union countries). ${ }^{14}$ The main reasons are a poorly defined cost-benefit balance in their own socioeconomic setting and important concurrent priorities for healthcare resource allocation. Additionally, some concern arose about a temporary increase in herpes 
zoster (HZ) after UV due to a lack of exogenous boosting. ${ }^{15} 16$ Although plausible and supported by mathematical models, this hypothesis remains a source of debate. ${ }^{17} 18$

In Belgium, varicella incidence is estimated around 113000 cases/year, leading to 28.8-35.7 general practitioners (GPs) visits $/ 10^{4}$ people per year. ${ }^{19}$ However, routine varicella vaccination is not yet recommended in our country. The vaccination coverage based on a subnational survey was estimated to be less than $2.5 \%$ (2-dose schedule). ${ }^{20}$ Few data are available on the real burden of varicella disease and on the potential benefits achievable from a national vaccination campaign in Belgium. In this study, we prospectively assessed the burden of varicella disease over the whole Belgian area through analysis of hospitalised cases during a 1-year period.

\section{METHODS}

Study design

This national survey was done in collaboration with the Scientific Institute of Public Health (SIPH). The study used a prospective design collecting all paediatric varicella-related hospitalised cases over a 1-year period (1 November 2011 to 31 October 2012) in Belgium. All paediatric wards were identified by cross between ministerial and national paediatric societies' registers. All teams were invited to participate by personal mailing and phone contacts, as well as through the recording system of the SIPH.

Inclusion of eligible cases was first prospectively carried out by local teams concomitantly to their routine practice and then retrospectively completed by a data-nurse reviewing admission files and computerised file summaries. Clinical and epidemiological data were recorded from medical files through a predefined electronic questionnaire. Data from non-participating centres were recorded on log sheets to estimate the incidence of disease as precisely as possible.

\section{Case definitions}

Strict definitions were used for varicella, varicella hospitalised case, complicated case and rash intensity that are provided in online supplementary appendix 1 .

\section{Study population}

All children aged $0-15$ years old meeting the above case definition were eligible, regardless of their comorbidity or previous medical history. Children with varicella but hospitalised for another reason or admitted for $<24 \mathrm{~h}$ were excluded. Nosocomial varicella infections were also excluded.

\section{Ethics}

The study protocol was approved by the ethics review committee of the coordinating centre (HUDERF) and submitted to the ethics committee of the other participating hospitals. To ensure confidentiality, patients were identified using their initials, date of birth and zip code only.

\section{Statistical analysis}

Epidemiological results are presented as rate of incidence of varicella disease (total and complicated hospitalised cases) by Belgian total and paediatric populations (population estimated for those aged $<16$ years in 2011-2012). Differences between groups were assessed by Fisher's exact test or $\chi^{2}$ test for noncontinuous variables and Mann-Whitney $U$ test for continuous variables. A two-tailed $\mathrm{p}$ value of $<0.05$ was considered as statistically significant.

\section{RESULTS}

\section{Epidemiological data}

We collected data from 101 hospitals, covering 97.7\% of the total paediatric beds available in Belgium. Five hundred and fifty-two children hospitalised for varicella were recorded during the study period. Based on the national demographic data available on 1 January $2012,{ }^{19}$ the incidence of varicella-related paediatric hospitalisations and of complicated hospitalised cases was $29.5 / 10^{5}$ and $19 / 10^{5}$ person-years, respectively (table 1 ). Hospitalisation policy seemed homogenous all over the country, since the distribution of collected cases followed exactly the percentage of population allocated to each of the three regions. The distribution of hospitalisation during the study year showed the usual seasonal varicella peak occurring around end of spring (May and June; data not shown).

The burden of disease was highest among preschool children who represented the major part of the entire study cohort, as well as of the complications (table 1). The proportion of complicated cases among hospitalised patients was quite similar between both 1-4 years and 5-14 years age groups (78\% and $75 \%$, respectively), but lower among children $<1$ year $(51 \%)$.

The incidence of varicella-related ambulatory visits was assessed at almost the same period through a sentinel network of GPs. ${ }^{19}$ Among the population $0-4$ years old, they reported an average of GPs varicella outpatient visits of $495 / 10^{4}$ peopleyear. Taken together with our findings, we could estimate the rate of hospitalisation per varicella case to be around $1.6 \%$ in that preschool population ( $0-4$ years old). Similar extrapolation led to a rate of hospitalisation for complications among all varicella cases of $1.0 \%$ in that age group.

\section{Patients' characteristics}

Baseline characteristics of our cohort study are summarised in table 2 . The vast majority of patients were younger than the age of 4 years old; 14\% (79/552) had at least one underlying chronic condition. Only four had received one dose of varicella vaccine that was administered within the month before hospitalisation except for one child vaccinated 6 months before admission.

\section{Clinical features and complications}

Fourteen per cent (79/552) of children presented with severe vesicular rash on admission, whereas $17 \% \quad(\mathrm{~N}=93)$ were reported to have only a mild eruption as defined above. The median time between the first lesions and hospitalisation was 3 days (range: $0-25$ days). The main reasons for hospitalisation were suspected bacterial infection (49\%), poor general status (20\%), dehydration/anorexia (11\%), the presence of neurological complications (10\%), concomitant pneumonia (9\%), high-grade persisting fever (6\%), stomatitis (5\%), underlying condition (5\%), age below 3 months (3\%) and social issues

Table 1 Incidence of varicella-related hospitalisations and mortality among Belgian children

\begin{tabular}{lllll}
\hline $\begin{array}{l}\text { Age } \\
\text { group } \\
\text { (years) }\end{array}$ & $\begin{array}{l}\text { N Belgian } \\
\text { children } \\
2011-2012\end{array}$ & $\begin{array}{l}\text { Incidence } \\
\text { hospitalisation } \\
\text { for varicella* }\end{array}$ & $\begin{array}{l}\text { Incidence } \\
\text { hospitalisation } \\
\text { for complicated } \\
\text { varicella* }\end{array}$ & $\begin{array}{l}\text { Mortality } \\
\text { rate }\end{array}$ \\
\hline $0-14$ & 1873326 & $29.5 / 10^{5}$ & $19 / 10^{5}$ & $0.5 / 10^{6}$ \\
$0-4$ & 647171 & $79 / 10^{5}$ & $51 / 10^{5}$ & $1.5 / 10^{6}$ \\
$5-14$ & 1226155 & $3.3 / 10^{5}$ & $2.45 / 10^{5}$ & 0 \\
\hline
\end{tabular}

*Person-years. 
(3\%). Poor general status, high fever and feeding difficulties justified admission in $34 \%$ of the youngest children ( $<2$ years). The median duration of hospital stay was short (3 days, IQR 25 ) but was up to 40 days in the most severe cases.

Sixty-five per cent (357/552) of children had one or more complications detailed in figure 1. Globally, the presence of any bacterial superinfection (not including pneumonia) represented two-thirds of complicated cases (235 children, $43 \%$ of the entire cohort). Bacterial skin and soft tissue infections were by far the most common (59\% of complicated cases, 204 children). Among episodes with an available microbiology, meticillin-susceptible Staphylococcus aureus and group A $\beta$-haemolytic Streptococcus were the main causal pathogens. Only three children had meticillin-resistant $S$. aureus infections. Neurological complications $(\mathrm{N}=56,10 \%)$ consisted in febrile seizures $(29 / 56)$, cerebellitis with ataxia (13/56), encephalitis (6/56) and meningitis (2/56). Forty-nine children ( $9 \%$ of the cohort) suffered from pneumonia; out of them, 21 (43\%) were recorded as having viral pneumonia, whereas in the remaining 28 (57\%), a bacterial aetiology was suspected and treated accordingly. Rare complications included haemorrhagic vesicular rash (two cases), staphylococcal scalded skin syndrome (one case) and disseminated vasculitic purpura (one case). Of interest, four babies had a neonatal varicella, all of which were self-limiting. No Reye's syndrome was reported.

\section{Treatments}

Only 26\% (141/544, 7 missing data) of children received acyclovir for a median duration of 5 days (IQR 3-5 days; maximum 21 days). Out of them, 72\% (101/141) received a complete intravenous course. Valacyclovir was not prescribed.

In contrast, $58 \%(322 / 552)$ of the children received antibiotic therapy that was administered intravenously for half of them. Drugs most prescribed were amoxicillin-clavulanate (31\%), penicillin or oxacillin (22\%) and clindamycin (7\%). The median duration of therapy was 7 days (IQR 5-10 days, range 1-42 days).

Invasive surgery was part of patient's management in 15 cases (3\%). Interventions consisted in abscess or pleural drainage, joint aspiration and wound debridement.

Paediatric intensive care unit (PICU) admission was required for 20 children (4\%), with a median stay duration of 5 days (range: 2-14 days). The main reasons for admission to PICU were encephalitis/seizures $(\mathrm{N}=5)$, sepsis with haemodynamic instability $(\mathrm{N}=4)$, poor general status with severe pain/dehydration $(\mathrm{N}=4)$, need for intensive observation due to underlying condition $(\mathrm{N}=3)$, severe combined immunodeficiency $(\mathrm{N}=1)$ and the presence of intestinal ileus $(\mathrm{N}=1)$. Four children $(20 \%$ of those admitted to PICU) needed mechanical ventilation and one $(5 \%)$ non-invasive ventilation support.

\section{Outcome}

One 17-month-old girl died from severe bacterial sepsis 6 days after her varicella rash started. The diagnosis of toxic shock syndrome due to group A $\beta$-haemolytic Streptococcus was suspected on clinical presentation though no microbiological confirmation could be obtained. The fatality rate among hospitalised cases and complicated hospitalised cases was $0.2 \%$ and $0.3 \%$, respectively. According to analysis of death certificate records, the varicella-related mortality rate inside the Belgian paediatric population that was around $0.5 / 10^{6}$ in our study was stable during the last decade ${ }^{21}$ and in line with other European reports (tables 1 and 3).

While the infection completely resolved in 99\% (547/552) of children, four of them (1\%) had sequelae at discharge consisting of reactive arthritis, ataxia, complex epilepsy or thrombophlebitis.
Table 2 Patients' baseline characteristics

\begin{tabular}{|c|c|}
\hline Total number of patients & 552 \\
\hline Sex ratio (M/F) & 1.3 \\
\hline \multicolumn{2}{|l|}{ Age (years) } \\
\hline Median & 2.1 \\
\hline IQR & $1-3.5$ \\
\hline Range & $0-15.7$ \\
\hline Age groups distribution & $\mathrm{N}(\%)$ \\
\hline $0-4$ years & $512(93)$ \\
\hline$<3$ months & $21(4)$ \\
\hline$<1$ year & $137(25)$ \\
\hline $5-14$ years & $40(7)$ \\
\hline Ethnicity & $\mathrm{N}(\%)$ \\
\hline Caucasian & $307(56)$ \\
\hline North Africa & $50(9)$ \\
\hline Sub-Saharan Africa & $17(3)$ \\
\hline Asia & $17(3)$ \\
\hline South America & $5(1)$ \\
\hline Oceania & $1(0.2)$ \\
\hline Unknown & $155(28)$ \\
\hline Comorbidity & N (\%) \\
\hline Lung disease & $22(4)$ \\
\hline Asthma & $17(3)$ \\
\hline Neurological disorder & $11(2)$ \\
\hline Renal disease/uropathy & $10(2)$ \\
\hline Cancer & $6(1)$ \\
\hline Cardiac disease & $6(1)$ \\
\hline Gastrointestinal disease & $5(1)$ \\
\hline Immunosuppressive therapy & $3(0.5)$ \\
\hline Congenital immunodeficiency & $3(0.5)$ \\
\hline Congenital malformation & $3(0.5)$ \\
\hline Haematological disorder & 2 \\
\hline Metabolic disorder & 1 \\
\hline Varicella vaccine status & N (\%) \\
\hline Unvaccinated & $322(58)$ \\
\hline 1 dose & $4(1)$ \\
\hline Unknown & $226(41)$ \\
\hline
\end{tabular}

Moreover, 9\% (51/552) of children were described as having significant skin scars.

\section{DISCUSSION}

In this national prospective study, we obtained data from $98 \%$ of paediatric inpatient units in Belgium, allowing us to reliably assess the burden of varicella disease in our country, both in terms of incidence and severity, and to identify the paediatric groups that will benefit the most from vaccination. Because the diagnosis of each varicella case was confirmed by a paediatrician, our data could be gathered in a more reliable manner compared with others using only hospital computed databases. ${ }^{27}$ Limitations have, however, to be recognised. First, some children might have been hospitalised for infectious complications secondary to recent varicella that was not identified by the clinicians as the risk factor. The national VZV burden observed here might therefore be underestimated. Second, our 1-year study did not allow controlling for year-to-year variations in varicella 
Figure 1 Distribution of varicella-related complications. $\mathrm{N}=357$ patients; $4 \mathrm{~S}=$ staphylococcal scalded skin syndrome.

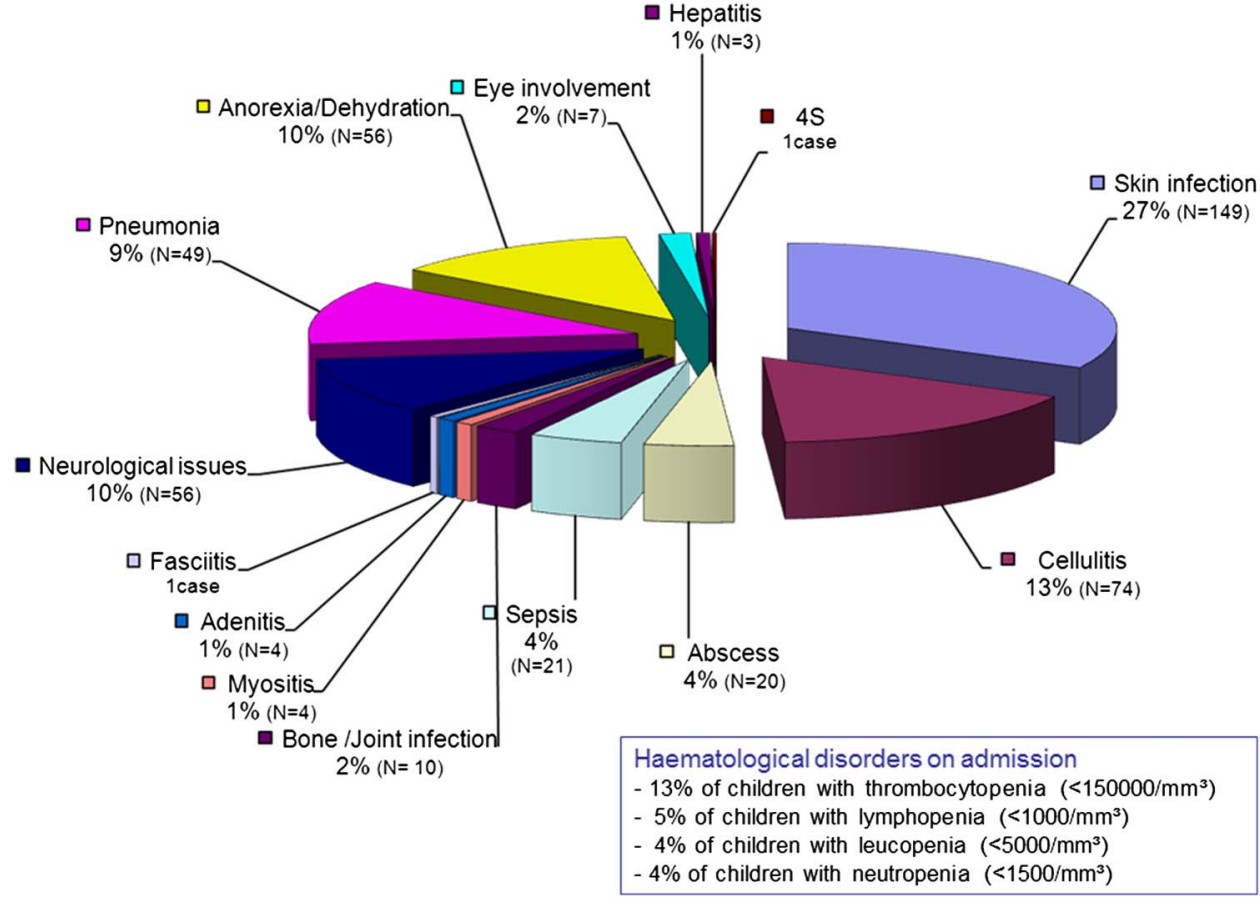

incidence. ${ }^{28}$ Although the reported incidence might have suffered from overestimation or underestimation, we demonstrated a significant burden of disease among the general childhood population with highest impact in previously healthy young children $(0-4$ years old). The varicella-related mortality was very low, but the duration of hospitalisation was $\geq 5$ days in $25 \%$ of subjects.

As detailed in table 3, our data show a much higher incidence of varicella hospitalisation than reported by other nationwide studies from Europe. ${ }^{22-24}{ }^{26}$ However, the design of these studies (eg, inclusion criteria, definitions of complication) varies widely from one country to another, making direct comparisons extremely difficult. Our results are nevertheless very similar to those from neighbouring Northern France, where Dubos $e a^{25}$ also included complicated and uncomplicated varicella cases. By including all varicella hospitalised cases regardless of their severity, we attempted to obtain a real life overview of varicella-related inpatients in our country. The reasons why more than one-third of children classified as uncomplicated varicella were hospitalised remain intriguing. The proportion of uncomplicated cases was the highest among infants, which could illustrate paediatricians' fear of varicella complications or parental difficulties in managing the disease. A high frequency of uncomplicated inpatient varicella cases $(20-43 \%)$ has also been reported in other European studies enrolling unselected hospitalised cases of varicella 252629 and deserves further investigation. Finally, it has recently been estimated that the incidence of paediatric outpatient visits for varicella in Belgium was 4950/10 5 person-years in children under the age of 5 years old. ${ }^{19}$ Taking into account our incidence of hospital admissions for varicella in this age group, we can estimate the corresponding rates of hospitalisation and of complicated hospitalisation among all varicella ambulatory cases to be around $1.6 \%$ and $1.0 \%$, respectively. This extrapolated result reflects a high burden of varicella disease but has, however, to be carefully considered, since the number of varicella outpatients could be overestimated (recurrent consultations for the same patient) or underestimated (additional visits to the paediatricians or to the emergency room).
UV against varicella has been highly successful in many countries. ${ }^{6}{ }^{4-12}$ In the USA, implementation of the one-dose varicella immunisation programme in 1997 led to a $89.8 \%$ decrease in the global incidence of varicella cases in $2005 .^{6}$ Substantial reduction in deaths, hospitalised cases, outpatient visits and medical costs related to varicella were also demonstrated. ${ }^{10}{ }^{11}$ In Germany, similar results were published despite a lower coverage rate with a one-dose schedule. ${ }^{12}$ A 2-dose schedule (including a second dose administered at variable ages) was recently implemented by most countries with UV programmes. ${ }^{13}$ This significantly improved the varicella vaccination effectiveness by a further reduction in disease incidence and breakthrough infections. ${ }^{30}$ Despite these successes, varicella UV remains debated in most European countries and recommended only for at-risk groups. ${ }^{27}$ Bonanni $e t a l^{31}$ have, however, concluded that vaccination targeting only adolescents and at-risk groups was unable to interrupt virus transmission and was much less efficacious than UV. Additionally, our study as well as others $^{22-24} \quad 28 \quad 32-34$ clearly demonstrate that most hospitalised children with varicella were previously healthy; this constant finding is a strong argument in favour of varicella UV. Our recent comprehensive national survey now supports the implementation of varicella UV in Belgium and at least fuels the debate in other European countries without UV.

Varicella vaccination has been shown to reduce the risk of $\mathrm{HZ}$ in vaccinated children, though very long-term surveillance remains needed. ${ }^{35}$ Debate continues about whether childhood varicella UV might have a negative impact on the incidence of $\mathrm{HZ}$ in adults with a history of varicella. ${ }^{15} 27{ }^{36}$ It has been postulated that re-exposure to circulating VZV might decrease the propensity of virus reactivation. ${ }^{15}$ If true, a consequence of this 'exogenous boosting' hypothesis could be a temporary increase of $\mathrm{HZ}$ cases following the reduced circulation of VZV under the influence of varicella vaccination. Whereas this could constitute a serious counterargument against UV, epidemiological surveys have not yet confirmed this hypothesis. ${ }^{37}$ Long-term follow-up in countries with UV demonstrated a slight increase in $\mathrm{HZ}$ incidence that, however, started before implementation of 
Table 3 Comparison of varicella burden in Europe

\begin{tabular}{|c|c|c|c|c|c|c|c|c|c|c|c|c|}
\hline & Country & Year & $\begin{array}{l}\text { Incidence } \\
\left(/ 10^{5} \text { person-years }\right)\end{array}$ & $\begin{array}{l}\text { Hospitalisation } \\
\text { rate } \\
\text { (/10 } \\
\text { cases) }\end{array}$ & $\begin{array}{l}\text { Cases } \\
\text { (n) }\end{array}$ & $\begin{array}{l}\text { Median } \\
\text { age } \\
\text { (years) }\end{array}$ & $\begin{array}{l}\text { Length of } \\
\text { hospital stay } \\
\text { (median in } \\
\text { days) }\end{array}$ & Complications & $\begin{array}{l}\text { Deaths } \\
\text { (n) }\end{array}$ & $\begin{array}{l}\text { Fatality rate } \\
\text { (/hospitalised } \\
\text { cases) }\end{array}$ & Sequelae & $\begin{array}{l}\text { Mortality rate } \\
\left(/ 10^{5} \text { person-years }\right)\end{array}$ \\
\hline \multirow[t]{2}{*}{ Cameron et $a l^{22}$} & $\begin{array}{l}\text { UK and } \\
\text { Ireland }\end{array}$ & $2002-2003$ & 0.82 & na & 188 & 3 & 7 & $\begin{array}{l}\text { Bacterial superinfections } \\
46 \%\end{array}$ & 5 & 2.6 & $\begin{array}{l}37 \% \\
\text { (ataxia) }\end{array}$ & 0.04 \\
\hline & & & $\begin{array}{l}\text { (severe hospitalised } \\
\text { cases) }\end{array}$ & & & & & CNS involvement $27 \%$ & & & & \\
\hline \multirow[t]{2}{*}{ Ziebold et $a^{23}$} & Germany & 1997 & 0.85 & 5 & 119 & na & na & $\begin{array}{l}\text { Bacterial superinfections } \\
61 \%\end{array}$ & 3 & na & $6.7 \%$ & na \\
\hline & & & $\begin{array}{l}\text { (severe hospitalised } \\
\text { cases) }\end{array}$ & & & & & CNS involvement 35\% & & & & \\
\hline \multirow[t]{2}{*}{$\begin{array}{l}\text { Bonhoeffer } \\
\text { et }\left.a\right|^{24}\end{array}$} & Switzerland & 2000-2003 & 5.9 & 13 & 420 & 3.5 & 5 & $\begin{array}{l}\text { Bacterial superinfections } \\
36 \%\end{array}$ & 3 & 0.5 & $4 \%$ & na \\
\hline & & & (all hospitalised cases) & & & & & CNS involvement $25 \%$ & & & & \\
\hline \multirow[t]{2}{*}{ Dubos et $a l^{25}$} & $\begin{array}{l}\text { North of } \\
\text { France }\end{array}$ & 2003 & 25 & na & 162 & 1.75 & 4 & $\begin{array}{l}\text { Bacterial superinfections } \\
29 \%\end{array}$ & 3 & 1.8 & na & 0.5 \\
\hline & & & (all hospitalised cases) & & & & & CNS involvement $26 \%$ & & & & \\
\hline \multirow[t]{2}{*}{ Liese et $a l^{26}$} & Germany & 2003-2004 & 14.1 & na & 918 & 3.3 & 5 & $\begin{array}{l}\text { Bacterial superinfections } \\
23 \%\end{array}$ & 10 & 1 & $8.7 \%$ & na \\
\hline & & & (all hospitalised cases) & & & & & CNS involvement $25 \%$ & & & & \\
\hline \multirow[t]{2}{*}{$\begin{array}{l}\text { National } \\
\text { Belgian survey }\end{array}$} & Belgium & 2011-2012 & 29.5 & na & 552 & 2.1 & 3 & $\begin{array}{l}\text { Bacterial superinfections } \\
43 \%\end{array}$ & 1 & 0.20 & $1 \%$ & 0.5 \\
\hline & & & (all hospitalised cases) & & & & & CNS involvement $10 \%$ & & & & \\
\hline
\end{tabular}

CNS, central nervous system. 
vaccination and was similar between regions, irrespective of their vaccine coverage. ${ }^{38}$ Moreover, a recent study demonstrated a comparable $\mathrm{HZ}$ incidence between specific adult communities not exposed to VZV and the general population. ${ }^{18}$ So far, the existence of exogenous boosting has been reported in some but not all studies ${ }^{16}$ and its importance, as well as the immune pathways involved, still needs to be determined. Further long-term studies assessing varicella and $\mathrm{HZ}$ burden are crucially needed in countries with UV to better elucidate this issue. Furthermore, vaccination against $\mathrm{HZ}$ for elderly people recently became available and started to be implemented in some countries. ${ }^{39}$

\section{CONCLUSION}

Varicella demonstrated a substantial burden of disease, especially among the youngest and previously healthy children. Our thorough nationwide study offers recent data to fuel the debate and supports varicella UV in European countries. However, some hypotheses still deserve further evaluation and postvaccination long-term surveys are needed to assess the effectiveness and costs-benefits of this new potential vaccination policy.

Acknowledgements We thank Mrs Véronique Léon for her constant and efficient technical support during the whole study. We thank Perle Rillon for her participation in data collection. We are grateful to all members of the Varicella Belgian Collaborative Study Group for their active participation in data collection.

Collaborators Members of the Varicella Study Group: W. Asscherickx, Algemeen Ziekenhuis Diest (Diest); H. Audiens, Algemeen Ziekenhuis Sint-Maarten (Mechelen); M. Azou, Algemeen Ziekenhuis Damiaan (Oostende); E. Baten, Algemeen Ziekenhuis Sint-Lucas (Brugge); Th. Bertrand, Centre Hospitalier Tubize-Nivelles (Nivelles); B. Beullens, Regionaal Ziekenhuis Sint-Trudo (Sint-Truiden); A-S Bouteiller, Centre Hospitalier Interrégional Edith Cavell (Brussels); B. Bruylants, Onze Lieve Vrouwziekenhuis (Aalst); B. Candi, Centre Hospitalier Régional Clinique Saint-Joseph - Hôpital de Warquignies (Mons); E. Cavatorta, Centre Hospitalier Universitaire André Vésale (Montigny-le-Tilleul) et CHU de Charleroi (Charleroi); I. Corthouts, Algemeen Ziekenhuis Sint-Blasius (Dendermonde); C. Croisier, Centre de Santé des Fagnes (Chimay); J. Delbushaye, Clinique Reine Astrid (Malmédy); L. De Lille, OLV van Lourdes Ziekenhuis Waregem (Waregem); S. Deman, Algemeen Ziekenhuis Sint-Lucas (Ghent); A. Demeester, AZ Delta, campus Menen (Menen); C. Denoncin, Cliniques du Sud-Luxembourg (Arlon); J-P. De Roeck, Centre Hospitalier de Mouscron (Mouscron); I. De Schutter, Universitair Ziekenhuis Brussel (Brussels): K. De Schynkel, Algemeen Ziekenhuis Maria Middelares (Ghent); A. de Selys, Clinique Saint-Jean (Brussels); H. Desimpel, Sint-Rembertziekenhuis VZW (Torhout); D. De Temmerman, Hôpital Erasme (Brussels); B. Duvivier, Intercommunale Hospitalière de Famenne Ardenne Condroz (Marche-en-Famenne); K. Eerdekens, Ziekenhuis Maas en Kempen (Bree); M. Elyahyioui, Centre Hospitalier Hornu-Frameries (Hornu); L. Fedora, Algemeen Ziekenhuis Lokeren (Lokeren); J. Franckx, Onze Lieve Vrouwziekenhuis (Asse); J. Frère and C. Lerusse, Centre Hospitalier Régional de la Citadelle (Liège); K. Garmyn, Heilig Hart Ziekenhuis VZW (Lier); C. Genin, Centre Hospitalier Chrétien (Montegnée); ML. Gielen, Algemeen Ziekenhuis Vesalius (Tongeren); E. Gueulette, Clinique Maternité Sainte-Elisabeth (Namur); L. Guzganu, Centre Hospitalier de Jolimont-Lobbes (Lobbes); N. Hemelsoet, Grand Hôpital de Charleroi (Charleroi); F. Henckens, Sint Franciskusziekenhuis (Heusden); J. Jaumotte, Centre Hospitalier de Dinant (Dinant); Ph. Jeannin, Algemeen Ziekenhuis Jan Palfijn (Ghent); L. Joachim, Centre Hospitalier Universitaire Tivoli (La Louvière); T. Jonckheer, GZA Ziekenhuizen (Antwerp); T. Khalil, Centre Hospitalier de Jolimont-Lobbes (Haine-Saint-Paul); S. Kreitz, Sint-Nikolaus Hospital (Eupen); P. Lemay, Algemeen Ziekenhuis Turnhout (Turnhout); F. Lemmens, Ziekenhuis Oost-Limburg (Genk); E. Lenga, Centre Hospitalier de la Haute-Senne (Soignies); J. Levy, Centre Hospitalier Universitaire Saint-Pierre (Brussels); A. Lubrez, Hôpital de la Madeleine (Ath); M. Maka, Clinique Louis Caty (Baudour); I. Matthijs, AZ Delta Roeselare (Roeselare); M. Michel, Clinique Saint-Pierre (Ottignies); M. Naert, Algemeen Ziekenhuis Sint-Jan Brugge-Oostende (Oostende); K. Naudts, Algemeen Ziekenhuis Sint-Elisabeth (Zottegem); A-M Nica, Centre Hospitalier Régional de Huy (Huy); A. Nobre-Machado, Hôpitaux Iris Sud (Brussels); L. Oosterlynck, Algemeen Ziekenhuis Groeninge (Kortrijk); S. Peeters, Algemeen Stedelijk Ziekenhuis (Aalst); J. Persyn, Sint-Andriesziekenhuis (Tielt); M. Pletincx, Centre Hospitalier Interrégional Edith Cavell (Brussels); M. Proesmans and F. Vermeulen, Universitair Ziekenhuizen Leuven (Leuven); K. Quaegebeur, Stedelijk Ziekenhuis (Roeselare); J-F. Questiaux, Centre Hospitalier Peltzer-La Tourelle (Verviers); M. Raes, Jessaziekenhuis (Hasselt); J. Ramet, Universitair Ziekenhuis Antwerpen (Edegem); F. Renders, Algemeen Ziekenhuis Sint-Augustinus (Veurne); A-M. Rentmeesters, Regionaal Ziekenhuis Heilig Hart (Leuven); N. Saive, Centre Hospitalier du Bois de l'Abbaye et de Hesbaye (Seraing); K. Sauer, Algemeen
Ziekenhuis Sint-Jan Brugge-Oostende (Brugge); P. Schelstraete, Universitair Ziekenhuis Gent (Ghent); K. Segers, Algemeen Ziekenhuis Sint-Jozef (Malle); M-C. Seghaye, Centre Hospitalier Universitaire Liège (Chenée); E. Sercu, Jan Yperman Ziekenhuis VZW (leper); T. Slaouti, Cliniques de I'Europe (Bruxelles); L. Snoeck, Algemeen Ziekenhuis Oudenaarde (Oudenaarde); J-Ph. Stalens, Centre Hospitalier de Wallonie Picarde (Tournai); J. Thijs, AZ Nikolaas (Sint-Niklaas); G. Tshibuabua, Center Hospitalier Régional du Val de Sambre (Auvelais); D. Tuerlinckx, CHU Dinant-Godinne (Godinne); G. Vandecasteele, Algemeen Ziekenhuis Sint-Dimpna (Geel); L. Van den Berghe, Sint-Vincentiusziekenhuis (Deinze); L. Vandenbossche, Mariaziekenshuis Overpelt (Overpelt); P. Vandenbroeck, Sint-Jozefskliniek VZW (Izegem); E. Vandenbussche, Algemeen Ziekenhuis Sint-Elisabeth (Herentals); A. Vander Auwera, GZA-Ziekenhuizen (Wilrijk); K. Vanderbruggen, Algemeen Ziekenhuis Zeno (Knokke-Heist); D. Van der Linden, Cliniques universitaires Saint-Luc (Brussels); S. Van Eldere, Imelda Ziekenhuis (Bonheiden); T. Van Genechten and I. Vlemincx, Algemeen Ziekenhuis Monica (Deurne); H. Van Hauthem, Regionaal Ziekenhuis Sint-Maria (Halle); B. Van Lierde, Algemeen Ziekenhuis Glorieux (Ronse); S. Van Lierde, Regionaal Ziekenhuis Heilig Hart VZW (Tienen); M. Van Oort, ZNA Koningin Paola Kinderziekenhuis Antwerpen (Antwerp); S. Van Steirteghem, Centre Hospitalier Universitaire Ambroise Paré (Mons); P. Verbeeck, Ziekenhuisnetwerk Antwerpen (Merksem); L. Verdonck, Algemeen Ziekenhuis Alma (Eeklo);

M. Verghote, Centre Hospitalier Régional (Namur); R. Verniest, Algemeen Ziekenhuis Klina VZW (Brasschaat); Ch. Versteegh, Centre Hospitalier Interrégional Edith Cavell (Braine-l'Alleud); P. Vincke, Centre Hospitalier de I'Ardenne (Libramont); Ph. Watillon, Clinique Notre-Dame de Grâce (Gosselies).

Contributors SB and PL designed the project and wrote the manuscript. SB did the data analysis. MS provided important help in data collection and analysis and contributed to improve manuscript writing.

Funding This study has been supported by a scientific unrestricted grant from GSK Belgium.

Competing interests PL has received an unrestricted grant from GlaxoSmithKline Biologicals, Belgium, to support the study. PL has received fees for serving on advisory board from GlaxoSmithKline Biologicals.

Ethics approval The study protocol was approved by the ethics review committee of the coordinating centre (HUDERF).

Provenance and peer review Not commissioned; externally peer reviewed.

Open Access This is an Open Access article distributed in accordance with the Creative Commons Attribution Non Commercial (CC BY-NC 4.0) license, which permits others to distribute, remix, adapt, build upon this work non-commercially, and license their derivative works on different terms, provided the original work is properly cited and the use is non-commercial. See: http://creativecommons.org/ licenses/by-nc/4.0/

\section{REFERENCES}

1 Heininger U, Seward JF. Varicella. Lancet 2006;368:1365-76.

2 Arvin AM. Varicella-zoster virus. In: Long SS, Pickering LK, Prober CG, eds. Principles and practice of pediatric infectious diseases. Churchill Livingstone Elsevier, 2008:1021-4.

3 Javed S, Javed SA, Tyring SK. Varicella vaccines. Curr Opin Infect Dis 2012;25:135-40.

4 Seward JF, Marin M, Vázquez M. Varicella vaccine effectiveness in the US vaccination program: a review. J Infect Dis 2008;197(Suppl 2):S82-9.

5 Seward JF, Watson BM, Peterson $C L$, et al. Varicella disease after introduction of varicella vaccine in the United States, 1995-2000. JAMA 2002;287:606-11.

6 Guris D, Jumaan AO, Mascola L, et al. Changing varicella epidemiology in active surveillance sites_-United States, 1995-2005. J Infect Dis 2008;197(Suppl 2): S71-5.

7 Salvadori MI. Preventing varicella: recommendations for routine two-dose varicella immunization in children. Canadian Paediatric Society Infectious Diseases and Immunization Committee. Paediatr Child Health 2011;16:415.

8 Marshall HS, McIntyre P, Richmond P, et al. Changes in patterns of hospitalized children with varicella and of associated varicella genotypes after introduction of varicella vaccine in Australia. Pediatr Infect Dis J 2013;32:530-7.

9 Siedler A, Arndt U. Impact of the routine varicella vaccination programme on varicella epidemiology in Germany. Euro Surveill 2010;15:pii:19530.

10 Zhou $F$, Harpaz $R$, Jumaan $A O$, et al. Impact of varicella vaccination on health care utilization. JAMA 2005;294:797-802.

11 Marin M, Zhang JX, Seward JF. Near elimination of varicella deaths in the US after implementation of the vaccination program. Pediatrics 2011;128:214-20.

12 Spackova M, Muehlen M, Siedler A. Complications of varicella after implementation of routine childhood varicella vaccination in Germany. Pediatr Infect Dis J 2010;29:884-6.

13 Centers for Disease Control and Prevention. Prevention of varicella: recommendations of the Advisory Committee on Immunization Practices (ACIP) MMWR Recomm Rep 2007;56(RR-4):1-40. 
14 ECDC Report. Varicella vaccine in the European Union. European Centre for Disease Prevention and Control. 2014.

15 Hope-Simpson RE. The nature of Herpes zoster: a long-term study and a new hypothesis. Proc $R$ Soc Med 1965;58:9-20.

16 Ogunjimi B, Van Damme P, Beutels P. Herpes zoster risk reduction through exposure to chickenpox patients: a systematic multidisciplinary review. PLOS ONE 2013;8:e66485.

17 Marin M, Meissner HC, Seward JF. Varicella prevention in the United States: a review of successes and challenges. Pediatrics 2008;122:e744-51.

18 Gaillat J, Gajdos V, Launay 0, et al. Does monastic life predispose to the risk of Saint Anthony's fire (herpes zoster)? Clin Infect Dis 2011;53:405-10.

19 Sabbe M, Vanthomme K, Top G, et al. Epidemiologie van windpokken en zona vastgesteld door huisartsen: 2006-2010. Vlaams Infectieziekte Bulletin 2012;4:5-10.

20 Robert E, Swennen B. Vaccination coverage survey of children (18-24 months) in the French community (Belgium), [Report in French], Provac, Ecole de Santé Publique, ULB, 2012

21 SPMA Standardized Procedures for Mortality Analysis-Belgium Public Health and Surveillance. Scientific Institute of Public Health, Brussels, Belgium. https://spma. wiv-isp.be (accessed 9 Sept 2014).

22 Cameron JC, Allan G, Johnston F, et al. Severe complications of chickenpox in hospitalised children in the UK and Ireland. Arch Dis Child 2007;92:1062-6.

23 Ziebold C, von Kries R, Lang $\mathrm{R}$, et al. Severe complications of varicella in previously healthy children: a 1-year survey. Pediatrics 2001;108:e79.

24 Bonhoeffer J, Bar G, Muchleisen B, et al. Prospective survey of hospitalisation associated with varicella-zoster virus infection in children and adolescents. Eur J Pediatr 2005; 164:366-70.

25 Dubos F, Grandbastien B, Hue V, Hospital Network for Evaluating Management of Common Childhood Diseases, Martinot A. Epidemiology of hospital admissions for paediatric varicella infections: a one-year prospective survey in the pre-vaccine era. Epidemiol Infect 2007;135:131-8.

26 Liese J, Veit $\mathrm{G}$, Rosenfeld $\mathrm{E}$, et al. The burden of varicella complications before the introduction of routine varicella vaccination in Germany. Pediatr Infect Dis J 2008;27:119-24.
27 KCE reports 151B. Rapport coût-utilité de la vaccination contre la varicelle chez les enfants, et de la vaccination contre le zona chez les adultes en Belgique. Centre fédéral d'expertise des soins de santé/Federaal Kenniscentrum voor de Gezondheidszorg. 2010.

28 Guess HA, Broughon DD, Melton LJ III, et al. Population-based studies of varicella complications. Pediatrics 1986;78(4 Pt 2):723-7.

29 van Lier A, van der Maas NAT, Rodenburg GD, et al. Hospitalization due to varicella in the Netherlands. BMC Infect Dis 2011;11:85

30 Bialek SR, Perella D, Zhang J, et al. Impact of a routine two-dose varicella vaccination program on varicella epidemiology. Pediatrics 2013;132:e1134.

31 Bonanni P, Breuer J, Gershon A, et al. Varicella vaccination in Europe-taking the practical approach. BMC Med 2009;7:26.

32 Jackson MA, Burry F, Olson LC. Complications of varicella requiring hospitalization in previously healthy children. Pediatr Infect Dis J 1992;11:441-5.

33 Law B, MacDonald N, Halperin S, et al. The Immunization Monitoring Program Active (IMPACT) prospective five year study of Canadian children hospitalized for chickenpox or an associated complication. Pediatr Infect Dis J 2000;19:1053-9.

34 Jaeggi A, Zurbruegg RP, Aebi C. Complications of varicella in a defined central European population. Arch Dis Child 1998;79:472-7.

35 Baxter R, Ray P, Tran TN, et al. Long-term effectiveness of varicella vaccine: a 14-year, prospective cohort study. Pediatrics 2013;131:e1389.

36 Bilcke J, van Hoek AJ, Beutels P. Childhood varicella-zoster virus vaccination in Belgium. Cost-effective only in the long run or without exogenous boosting? Hum Vaccin Immunother 2013;9:812-22.

37 Reynolds MA, Chaves SS, Harpaz R, et al. The impact of the varicella vaccination program on herpes zoster epidemiology in the United States: a review. J Infect Dis 2008;197(Suppl 2):S224-7.

38 Leung J, Harpaz R, Molinari NA, et al. Herpes zoster incidence among insured persons in the United States, 1993-2006: evaluation of impact of varicella vaccination. Clin Infect Dis 2011;52:332-40.

39 Williams WW, Lu PJ, O'Halloran A, et al. Vaccination coverage among adults, excluding influenza vaccination-United States 2013. MMWR 2015;64:95-102. 